\title{
Lacanyen Yaklaşımda Histeriğin Arzusu ve Arzunun Tatminsizliği
}

\author{
Derya Özbek Şimşek \\ Orta Doğu Teknik Üniversitesi
}

\section{$\ddot{O} z$}

Lacanyen analiz yapısal bir yaklaşım çerçevesinde oluşturulmuştur ve üç temel yapıyı içermektedir. Bu temel yapılar psikoz, nevroz ve perversiyon olarak adlandırılmıştır. Tanımlanan yapısal kategoriler öznenin tekrar geri getirilemeyecek ya da bulunamayacak bir kayba olan reaksiyonuna işaret etmektedir. Özne, yaşadığı kaybın üstesinden farklı mekanizmalar kullanarak gelmeye çalışmaktadır. İçinde bulunduğu kaybın etkileriyle baş edebilmek için kendini farklı şekillerde konumlandırmaya çalışır ve temel yapısının özelliklerine uygun olarak şu başlıca baş etme mekanizmalarını kullanır: bastırma (repression), reddetme (disavowal) ve hesaptan düşme (foreclosure). Temel yapısal kategorilerin yanısıra Lacanyen yaklaşımda bir de alt kategoriler bulunmaktadır. Örneğin, nevroz temel yapısının üç alt kategorisi bulunmaktadır. Bunlar histeri, obsesyon ve fobidir. Alt kategoriler belli başlı semptomlara göre sınıflandırılmanın aksine öznenin Öteki ve nesneyle ilişkilenme biçimi esas alınarak sınıflara ayrılmışlardır. Mevcut çalışmanın konusu nevrotik yapının alt kategorisi olan histeri olarak belirlenmiştir. Histerik yapının Öteki ve nesneyle olan ilişkisinin, yapının en belirgin özelliği olan histeriğin arzusu kavramı üzerinden tartışılması amaçlanmıştır. Bu sebeple, ilgili literatür bilgileri verildikten sonra bahsedilen özellik çerçevesinde bir vaka örneği geriye dönük (retrospektif) bir yaklaşımla ele alınarak incelenmiştir. Vakanın histerik yapıyı düşündüren özellikleri, "arzunun tatminsizliği" ve "arzulanan olmak" kavramları üzerinden tartışılmıştır. Ayrıca çalışmanın son kısmında literatür bilgisiyle uyum gösterecek şekilde terapi sürecine yer verilmiştir. Süreç içinde dikkat çekici bir nokta olan histeriğin kendi ve Ötekinin arzusuna yönelik sonu gelmez sorularına karşı terapistin alması beklenen pozisyon çalışmanın kapsamına dahil edilmiştir.

Anahtar Sözcükler: Lacan, histeri, arzu, tatminsizlik, histerik söylem 


\title{
A Lacanian Approach to a Case of Hysteria: The Desire of the Hysteric
}

\author{
Derya Özbek Şimşek \\ Middle East Technical University
}

\begin{abstract}
Lacanian diagnostic criteria are developed from a structural point of view, including only three main categories which are neurosis, psychosis, and perversion. These structures correspond to a fundamental loss. Therefore, the subjects try to manage it in different ways, such as repression, foreclosing, and disavowal. These are the ways in which the subjects position him-/herself in relation to loss in order to overcome its effects. In Lacanian psychoanalysis, there are subcategories as well. For example, the subcategories within neurosis are hysteria, obsession, and phobia. Additionally, rather than being categorized on the basis of specific set of symptoms, they are based on different relations to the Other and to the object. Thus, the main interest of this article will be on hysteria. The hysteric's relation with the Other and the object will be discussed by focusing on one of the most distinguishing features of the hysterical structure, the hysterical desire. A case example will be given in accordance with the provided literature. The dominant determinative feature of the case is described as a desire for "an unsatisfied desire" as well as a desire "to be desired." In the last part of the article, the therapy process will be reviewed. Also, the therapist's stance in approaching the hysteric's never-ending questions to find the knowledge of herself and the Other's desire will be covered.
\end{abstract}

Keywords Lacan, Hysteria, Desire, Unsatisfied Desire, Hysterical Discourse 


\section{Lacanyen Yaklaşımda Histeriğin Arzusu ve Arzunun Tatminsizliği}

Lacanyen analiz ağırlıklı olarak Freud'un çalışmalarına dayanmaktadır (Fink, 1997); ancak Freud'un kuramındaki dinamik etkileşime olan vurgunun aksine Lacan, Freudyen bilinçdışının yalnızca dürtü kuramıyla tanımlanamayacağını belirterek onu yeniden yorumlamış ve kuramında yapısal bir yaklaşıma yer vermiştir (Gessert, 2014). Lacan ayrıca gözlemlenen her bir semptomu ayrı bir hastalık olarak kabul ederek kategori sayısını artırmak yerine, temel yapılar arasındaki ayrımı oldukça basit tutmuştur (Fink, 1997). Bu sebeple nevroz, psikoz ve perversiyon olmak üzere yalnızca üç yapı üzerinden oluşturmuştur.

Lacanyen yaklaşımda yapısal analiz, günümüz psikiyatrisinde ön planda tutulan tanı kriterlerinden ve psikopatoloji yaklaşımlarından çok daha önemli görülmektedir. Çünkü günümüzde yaygın olarak kullanılan tanı kategorileri öznenin temelindeki oluşumların etkisini göz ardı etmekte, psikanalitik çalışmalar tam da bu noktada başlamaktadır (Fink, 1997). Lacan’a göre yapısal yaklaşımdaki önemli olan nokta şudur ki aslında tüm bireyler yaşamın başlangıcında bir gizem ya da bilmece ile karşı karşıya kalmaktadırlar. Bireyler var olmanın ya da mevcudiyetin gizemi ile yüz yüze gelmektedirler. Varlığın özünde bir boşluk oluşmaktadır ve aslında bireyleri “var” eden bu boşluk ya da eksikliktir. Tarif edilen var oluştaki boşluk temel bir kayba (fundamental loss) işaret etmektedir. Özne, eksiklik duygusundan kurtulma umuduyla ya da hayat üstünde etkili olduğunu görme çabası ile mücadele etmekte ve bu kaybın üstesinden gelebilmek için farklı yollar denemektedir. Kullanılan farklı yollar bahsi geçen Lacanyen yapılar ile (nevroz, psikoz ve perversiyon) uygunluk göstermektedir (Gessert, 2014). Bu noktada sözü edilmesi önemli bir husus; Lacanyen yaklaşımda normallik için bir yapının tanımlanmamış olmasıdır. Çünkü Lacan’a göre tüm bireyler kaybın psikolojik travmasına maruz kalmış ve kaybolanın geri getirilmesinin imkansızlığıyla yüzleşmiştir (Gessert, 2014).

Özne, kayıp nesneye tekrar ulaşmanın sonsuza dek mümkün olmayışı ve böylelikle de varlıktaki eksikliğin (kökensel yarı̆̆ın) doldurulamayacağı gerçeği ile karşılaştığında, bu kayıp deneyimiyle farklı şekillerde baş etmeye çalışmaktadır (Gessert, 2014). Örneğin, nevrotikler öznenin eksik olduğu bilgisini bilinç düzeyinden geri çevirerek bastırma mekanizması aracılığıyla baş ederken; psikotikler öznenin eksikliğine dair tüm bilgileri baştan önleyerek, hiç kabul etmeyerek, tümüyle silerek ya da hesaptan düşürerek işlerler. Pervertlerin durumunda ise özne eksiklik bilgisini reddetmektedir. Görüldüğü gibi nevrotik, psikotik ve pervert yapılar çeşitli pozisyonlar alarak kayıp deneyimi ve etkisiyle baş etmeye çalışmaktadırlar (Gessert, 2014). 
Temel yapısal kategorilerin yanısıra Lacanyen psikanalitik yaklaşımda ayrıca alt kategoriler de bulunmaktadır. Örneğin, nevroz temel yapısının üç alt kategorisi bulunmaktatır. Bunlar histeri, obsesyon ve fobidir. Alt kategoriler belli başlı semptomlara göre sınıflandırılmanın aksine öznenin Öteki ile ilişkilenme biçimi esas alınarak sınıflara ayrılmışlardır (Fink 1995; Fink, 1997). Nevrotik yapının alt kategorileri ile devam etmek gerekirse; histeri ve obsesyon, nesne ve Ötekiyle ilişkilenmeleri bakımından birbirlerine zıt bir şekilde pozisyon alma ya da yapılanma göstermektedirler. Obsesif yapıda, öznenin söylemi tamamen kendi etrafında dönmekte ve kendi odaklı olmaktadır. Ayrıca obsesif birey kendi dünyası içinde sarıp sarmalanmış gibi gözükmekte ve kendine ait bir adada tek başına yaşamaktaymış gibi tarif edilmektedir. Histerik yapıda ise durum tam tersidir. Histerik bireyin dünyası insanla dolmuş/doldurulmuştur. Histerik birey kendisini ilişkide olduğu insanlarla tanımlamaktadır (Fink, 1997). Lacan da benzer şekilde histeriyi en basit haliyle, öznenin nesneyle olan ilişkisi olarak tanımlamıştır (Soler, 1996).

Bu sebeple, yukarıda belirtilen ayırıcı özellikler dikkate alınarak, mevcut çalışmanın konusu nevrotik yapının alt kategorisi olan histeri olarak belirlenmiştir. Histerik yapı birçok farklı ve ayırıcı özelliği olması sebebiyle çok çeşitli şekillerde açıklanabilmektedir. Ancak bu çalışmada özellikle "histeriğin arzusu” kavramı üzerinde yoğunlaşılmıştır.

\section{Histeriğin Arzusu}

Lacan nevrotiğin asıl çıkmazının var olma sorusu "ben neyim" olduğunu belirtmektedir. Bu sorunun çocuğun ebeveynlerinin (Ötekinin) arzusunu araştırmaya başladığı ilk andan itibaren ortaya çıkan bir soru olduğunu ifade etmektedir. "neden bana sahip oldular" ve "benden ne istiyorlar" ya da “annem için nasıl bir yer işgal ediyorum” soruları çocuğun ebeveynlerinin arzusundaki yerini anlamak için sorduğu sorulardır. Ancak bu soruların cevaplarını ebeveynlerin tutarsız ve değişken söylemlerinde ve davranışlarında bulmak çok zordur. Lacan'a göre cevaplar aslında fantezide (fundamental fantasy) gizlidir (Fink, 1997). Bu nedenle nevtorik bir yapı olan histeriyi anlamak için Lacan'ın fantezi kavramını incelemekte fayda vardır (Fink 1997).

Lacanyen yaklaşımda fantezi, bebeğin (öznenin) anneden ayrılmaya (separation) ve nesne kaybına (the loss of the object) tepkisi olarak düşünülmektedir. Histeriğin fantezisinde özne, ayrılma deneyimiyle kendisini Ötekinin kaybettiği olarak hayal ederek mücadele etmeye çalışmaktadır. Başka bir deyişle, özne ayrılma deneyiminin üstesinden Ötekini tamamlamak suretiyle gelmektedir. Ayrılma sürecinde özne, kendisinin kaybını annesinin kaybı üzerinden anlamlandırmakta ve annesi için “eksilen” nesne olmaktadır (Fink 1997). Bir başka ifadeyle, özne annesinin bebeği yani kendisi olmadan tam/bütün olmayacağını varsaymakta ve bu sebeple kendisini annesini tamamlamak ya da eksiğini doldurmak için gerekli olan nesne olarak kurmaktadır. Böylelikle özne kendi varlığını da 
oluşturmuş olmaktadır (Fink, 1997; Gessert, 2014). Görüldüğü gibi bebek kendini annenin kayıp nesnesi olarak konumlandırır. Annesinin eksiğini tamamlayacak nesne ile özdeşleştiğinde hem annesi tamamlanacak hem de kendisi var olacaktır. Anne ve bebek arasındaki ikili ilişki babanın adının (the Name-of-the-Father) devreye girmesiyle birlikte üçlü bir yapıya dönüşmekte ve bebeğin annesini bir Öteki olarak tamamlama stratejisi erkek bir Ötekine transfer edilmektedir. Histerik birey ileriki hayatında, en azından kısmen, bu stratejisini erkek partnerleriyle olan ilişkisinde yeniden oluşturmakta, tekrarlamaktadır (Fink, 1997). Öteki ile olan ilişkilerinde kendisini Ötekinin kaybettiği ya da arzuladığı nesne ile bütünleştirmektedir (Fink, 1997).

Histerik özne her zaman Ötekinin arzusu hakkında meraklı ve ilgilidir. Histerik, Ötekinin arzusunu tahmin etmeye ve Ötekinin kaybettiği ve arzuladığı o belirli nesne olmaya çalışır (Fink, 1997; Soler, 1996). Öyle ki, histerik kendisini ulaşılamaz arzu nesnesi (object $a$ ) olarak konumlandırmaktadır. Diğer bir deyişle, histerik arzulanabilmek için arzu nesnesiyle özdeşleşmektedir (Fink, 1997; Lacan, 1970; Eyers, 2012). Histeriğin fantezisinde, Öteki arzulayan öznedir ve histerik arzulanan nesne olarak Ötekine hakim olmak, ona egemen olmak istemektedir. Aslında histerik, Ötekinin arzusunun tatmin edilmemiş ya da yerine getirilmemiş olduğundan emin olmak için onu kontrol etmek ve yönetmek istemektedir. Neticede, histeriğe arzulanan nesne ya da Ötekinin eksiği rolünü kalıcı olarak tahsis eden bu doyurulmamış arzudur. Bir başka ifadeyle, histerik Ötekinin arzusunu tatminsiz bırakır çünkü Öteki arzulamaya devam ettiği sürece nesne olarak kendi konumu güvenceye alınmıştır. Ötekinin arzusunda bir yer onun varlığını oluşturabilmesi için muhafaza edilmiştir (Fink, 1997).

Histeriğin Ötekinin arzusunu doyurmama üzerine olan mücadelesini biraz daha açıklayabilmek adına, Freud'un bir vakası (the butcher's wife) örnek olarak incelenebilir. Bahsedilecek olan vaka yalnızca kısa bir rüyadan oluşmaktadır. Freud bu vakadan "Düşlerin Yorumu” kitabında "Rüyalarda Çarpıtma” isimli bölümde (The Interpretation of Dreams, Distortions in Dreams, 1900) bahsetmiştir. Ardından Lacan da “Tedavinin Yönü ve Gücünün İlkeleri” (Ecrits, The Direction of Treatment and the Principles of Its Power, 1958) adlı yazısında aynı vakaya değinmiştir. Freud'un hastası rüyasını şöyle anlatmaktadır:

Akşam yemeği için bir parti vermek istedim ama evde bir parça tütsülenmiş somon balığından başka bir şey yoktu. Dışarı çıkıp bir şeyler almayı düşündüm ama günlerden Pazar ve bütün dükkanların kapalı olduğunu anımsadım. Bunun üzerine yemek satan birkaç yeri aramaya başladım ama telefonlar arızalıydı. Sonuçta parti verme arzumdan vazgeçmek zorunda kaldım. (Freud, 1900, s. 174)

Rüya buraya kadar anlamlı ve tutarlı bir şekilde, bir arzunun gerçekleşmesinin tersi gibi gözükmekte iken Freud hastasına rüyayı başlatan şeyin her zaman için önceki günün olaylarında aranması 
gerektiğini söylemiştir. Böylece hastası bir gün önceye dair şu bilgileri paylaşmıştır: Bir gün önce et toptancısı olan kocası çok şişmanladığını ve bu nedenle katı bir rejime başlamak istediğini, bu sebeple de karısının artık hiçbir yemek daveti düzenlemesini istemediğini söylemiştir. Aynı konuşmanın devamında, Freud'un çağrışımlarını desteklemesiyle hasta şöyle devam etmiştir: Yine bir gün önce kocasının sürekli övgüyle bahsettiği ve bu yüzden de kıskandığını itiraf ettiği bir kadın arkadaşını ziyaret etmiştir. Kadın arkadaşıyla ilgili olarak da, neyseki onun kocasının ilgisini çekemeyecek kadar cılız olduğunu, kocasının kendisi gibi dolgun kadınlardan hoşlandığını söylemiştir. Ayrıca, görüşmeleri esnasında arkadaşının son zamanlardaki kilo alma isteğinden bahsettiğini ve ona kendilerini ne zaman yemeğe davet edeceğini sorduğunu hatırlamıştır (Freud, 1900).

Freud' a göre rüyalar her zaman arzuların gerçekleşmesi savını desteklemez, tam tersine bazen arzunun gerçekleşmemiş olması diğer bir arzunun gerçekleşmesi anlamına gelmektedir. Örneğin, bahsedilen rüyada, rüyanın içeriği ilk bakışta bir isteğin gerçekleşmemesi olarak görülmektedir. Hasta rüyasında arzuladığı yemek davetini verememiştir. Ayrıca arkadaşının da yemek daveti gerçekleşmediği için kilo alma arzusu gerçekleşmemiştir. Her ne kadar rüyanın görünen içeriği tam tersini gösteriyor olsa da aslında rüya, hastanın arkadaşına kilo alması konusunda yardım etmeme isteğini ya da kilo almasının gerçekleşmemesi arzusunu göstermektedir çünkü Freud'a göre hastası arkadaşının kilo alarak kocasına çekici görünmesini istememektedir. Hastanın bu düşüncesinin oluşması ve rüyaya yansımasında kocasının partilerde yenilen yemeklerin insanları şişmanlattığı bu yüzden kilo vermek için yemek davetlerinden uzak durması gerektiği kararı etkili olmuştur. Hasta, arkadaşının kilo alarak çekici görüneceğini ve kocasının gözündeki arzulanan nesne olma rolünü elinden alacağını düşünmektedir (Freud, 1900); bu sebeple, arzulanan nesne olarak yerini korumak istemekte ve arkadaşına kocasının arzusunu doyurma firsatını vermek istememektedir.

Rüyadaki ikinci derece bir anlam da yemek davetindeki somon balığı ayrıntısıyla dikkat çekmiştir. Hastaya rüyadaki balığın nerden gelmiş olabileceği sorulduğunda, tütsülenmiş somon balığının arkadaşının en sevdiği yemek olduğunu söylemiştir. Bu ayrıntı, hastanın rüyasında kendisini arkadaşının yerine koymuş olabileceğini düşündürmüştür. Çünkü arkadaşı kocasının gözünde onun yerini almaktadır. Hasta, arkadaşının aldığı yerini geri almak istemiştir (Freud, 1900).

Hastanın arzusuyla ilgili olabilecek bir başka içerik; hastanın uzun süredir kocasına her sabah havyarlı bir sandviç yemek istediğini söylerken, kocası almak istediğinde pahalı olduğunu söyleyerek büyük bir kararlılıkla almasını istemediği dile getirmesi, ayrıca bu konuda konuşmaktan ve kocasını rahatsız etmekten de geri durmamasıdır (Freud, 1900). Hastanın bu şekilde davranarak 
kocasında, kendisine arzuladığı havyarı vermekle ilgili bir arzu oluşturduğu ama kocasının gözündeki arzuyu sürdürebilmek için de bu arzunun doyurulmasına, hayvarın satın alınmasına, müsaade etmediği düşünülmüştür. Kocasına havyar yeme isteğini sık sık hatırlatarak, kocasının arzusunu canlı tutmayı amaçlamaktadır. Kısaca kocasında oluşturduğu eksiği, arzusunu vurgulayarak ama tatmin edilmesine izin vermeyerek sürdürmektedir (Fink, 1997). Böylelikle kocasının ona istediğini verme arzusu uyarılmış ama giderilmemiş olarak kalacak ve kendisi arzulanan konumunu sürdürebilecektir.

Lacan'1n 11. Seminerinde (1981, s. 38) belirttiği gibi, histeriğin arzusu Ötekinin arzusudur. $\mathrm{Bu}$ örnekte de açıkça görülmektedir ki, histerik arzusunun tatminini aramamaktadır. Aksine histeriğin odağı Ötekidir (Soler, 1992; Soler, 1996). Daha önce de ifade edildiği gibi, histeriğin varlığı Ötekine, Ötekindeki belirli bir eksikliğe ya da güçsüzlüğe dayanmaktadır (Lacan, 1981). Bu sebeple, histerik bilinçdışı bir şekilde Ötekinin eksiği olmayı arzular ya da Ötekinin arzusu olan gösteren olmayı arzular (Soler, 1992; Soler, 1996).

Benzer şekilde, histerik özne Ötekinin arzusunun hakimi olmak ya da Ötekinin arzusunun nedeni olmak istemekte; ancak aynı zamanda Ötekinin arzusunu doyurduğu kişi olmak istememektedir (Fink, 1997). Aslında histeriğin isteği, Ötekinin zevkinin (jouissance) olumsuzlanması ya da etkisiz hale getirilmesidir (Soler, 1992). Histerik, Öteki ile ilişkisinde aniden kaçmakta ve böylece Ötekinde bir eksik meydana getirmektedir. İhtiyaç duyulduğunda ortada olmayan ve partnerini her zaman yüzüstü bırakan kişi olarak tarif edilmektedir. Çünkü histerik, arzunun sebebi olmak istemesine rağmen, Ötekinin zevk aldığı olmayı reddetmektedir (Fink, 1997; Soler, 1996). Böylece histeriğin zevkinin arzulanabilir olmakla veya arzunun nesnesi olabilmekle sınırlı olduğu görülmekte, ama arzunun tatminini sağlayan nesne olmak istemediği anlaşılmaktadır (Gherovici, 2014). Öyleyse histerik aslında yalnızca "fallus" diğer bir ifadeyle Ötekinin eksiği, bulunamayan ama hep aranan nesnesi olmayı arzulamaktadır (Soler, 1992).

Sunulan bilgileri destekler şekilde, Lacan (1960) histeriğin durumunda arzunun fantezide sürdürüldüğ̈̈nü ve sadece tatminin eksikliği ile mümkün olduğunu; bu nedenle de arzunun nesnesi olmayı arzulayan histeriğin, gözden kaybolarak eksik olanın arzusunu oluşturduğunu belirtmiştir. Lacan, ayrıca öznenin ortadan kaybolduğunda iki şey elde ettiğinden bahsetmiştir. Bunlardan ilki, özne Ötekinin arzusunun tatminini reddederek eksikliğin devamını, böylece arzunun sürekliliğini sağlaması iken; ikincisi öznenin kendi tatminsizliğini sürdürmesidir. Böylece histerik hem kendinin hem de Ötekinin arzular halini devam ettirmektedir. Ayrıca, özne Ötekinin zevkinin bir parçası olmayı reddererek kendini de zevkten mahrum bırakmakta ve aslında gözden çıkardığı zevk, özne için asıl tatminin sağlandığı noktadır (Palomera, 2012). Örneğin, histeri vakalarının klinik 
gözlemlerinde histerik öznenin ilişkilerinde mazosişt bir pozisyon alıyor olması dikkat çekmektedir. Bu mazoşist konum mazoşizm olarak değerlendirilmemelidir. Aksine bu durum histerik özne için “yoksunluğun/mahrumiyetin cezbediciliği” ile ilişkilidir. Özne bir arzu tarafindan uyarılır ve o arzunun işlevi de öznenin alacağı zevki ya da tatmini etkisiz duruma getirmektir (Soler, 1992).

Histerik arzunun bir diğer özelliği, öznenin tatmini olmayan arzuyu arzulamasıdır (Fink, 1997). Lacan, histerik yapıyı arzunun tatminsizliği ile tanımlamış (Lacan, 1961) ve histeriğin ilksel bir tatminsizliği sembolize ettiğini belirtmiştir (Lacan, 1970). Örneğin, Freud'un daha önce sözü geçen vakasında, hasta tütsülenmiş somon balığının arkadaşının en sevdiği yemek olduğunu ama arkadaşının kendisini somon yemekten yoksun bıraktığını söylemiştir (Freud, 1900). Birey bir şeyi çok arzulamasına rağmen kendini ondan mahrum bırakıyorsa, yalın bir biçimde o arzusunu devam ettiriyor olarak düşünülmektedir. Diğer bir ifadeyle, birey arzuladığı ya da istediği şeyi elde etmeyi reddediyorsa, arzusunu doyurulmamış olarak sürdürüyor demektir (Soler, 1996). Freud'a göre hastası da arkadaşına benzer şekilde davranmaktadır. Kocasına havyarı sevdiğini ve yemek istediğini söylemesine rağmen, kocasının almasına müsaade etmemekte, çünkü böylelikle arzusunu sürdürebilmektedir (Freud, 1900). Hasta bu durumda aslında yalnızca istiyor olabilmekten ve kendisini arzuladığı şeyden yoksun bırakıyor olmaktan zevk duymaktadır. Daha açık bir ifadeyle, yoksunluk deneyimi ya da arzuyu sınırlama, özne için başlı başına keyif verici olmaktadır (Fink, 1997). Bu nedenle, histeride yoksunluk için bir arzu bulunmaktadır şeklinde bir sonuca gitmek yanlış olmayacaktır (Freud 1900; Lacan, 1958; Soler, 1992).

Bahsedilen vakadan yola çıkarak Lacan, rüyanın aslında arzunun bir metaforu olduğunu belirtmiş ve histerinin arzusunun tatminsiz bir arzuya yönelik olduğunu eklemiştir (Lacan, 1958). Metafor, bir gösterenin bir başka gösterenle yer değiştirmesi, ikame edilmesi anlamına gelmektedir (Soler, 1992; Soler, 1996). Örneğin, hastanın anlatımındaki arkadaşının tütsülenmiş somona olan arzusu, hastanın havyara olan arzusunun yerine geçmiştir (Lacan, 1958). Lacan bu durumu hastanın tatminsiz arzuya olan arzusunun, havyara olan arzuyla gösterildiği şeklinde yorumlamıştır (Lacan, 1958). Dolayısıyla havyar için olan arzu aslında doyurulamayacak olan arzuya olan arzuyu işaret etmektedir (Soler, 1992).

Çalışmanın izleyen bölümünde M. Hanım vakası daha önce belirtilen histeriğin arzusu odaklı yazın ile bağlantılı olarak geriye dönük bir yaklaşımla tartışılacaktır. M. Hanım histerik yapıyı işaret eden birçok özelliği sergiliyor olmasına rağmen, vaka baskın ayırıcı özellikler olan "arzunun tatminsizliği” ve “arzulanan olmak” kavramları üzerinden ele alınacaktır. M. Hanım'ın arzusu seanslara getirdiği örnekler üzerinden açıklanmaya çalışılacaktır. Öncelikle demografik bilgilerinin ve terapiye gelmesine sebep olan şikayetlerinin kısa bir tanımlaması yapılacak, ardından seçilen 
histerik özellik üzerinden detaylı bir tartışmaya yer verilecektir. Ayrıca çalışmanın son kısmında terapi süreci değerlendirilecektir.

\section{Hanım Vakası}

M. Hanım 25 yaşındadır ve bir üniversitede araştırma görevlisi olarak çalışmaktadır. Aynı zamanda doktora eğitimine de devam etmektedir. M. Hanım kendisi ile aynı meslekten olan E. Bey ile nişanlıdır ve aynı evi paylaşmaktadırlar. M. Hanım dört kişilik çekirdek bir ailenin büyük çocuğudur. Anne ve babası 50'li yaşların başındadır. Annesi ev hanımı olup babası üretim sektöründe çalışmaktadır. M. Hanım'nin kendisinden altı yaş küçük kardeşi üniversite son sınıf öğrencisidir. M. Hanım ailesini destekleyici ve ihtiyaçlarına duyarlı olarak tanımlamaktadır. Babasını "çalışkan, sakin, inançlı, metanetli ve herkese yardım eden"; annesini de "hayatını başkalarına adamış, kötü şeyleri görmeyen, aşırı fedakar birisi” olarak belirtmiştir.

M. Hanım nişanlısını "bencil, baskıcı ve tehditkar" olarak tanımlamıştır. E. Bey’in bu özelliklerini başlangıçta “iyi özellikler” olarak gördüğünü çünkü kendisinin “narin, kırılgan ve sorunlarla çok fazla baş edemeyen birisi”" olduğunu, bu sebeple de E. Bey’i "güçlü, savaşç1, koruyucu ve sorumluluk sahibi birisi” olarak gördüğünü belirtmiştir. Böylece E. Bey’in kendisine karş1 "herkesi yola getirebilecek birisi” olabileceğini düşündüğünü söylemiştir.

M. Hanım kliniğe başvuru nedenini kaygı ve endişe sorunları olarak tanımlamıştır. Hayatının birçok alanında ve birçok farklı durumda yoğun bir kaygı duygusu yaşadığını ve bazı psikosomatik semptomları olduğunu belirtmiştir. Bu semptomları zaman zaman kalp çarpıntısı, nefes almada güçlük ve gevşeyememe şeklinde kendisini göstermektedir. M. Hanım işi, nişanlısı ve hayatının gidişi ile ilgili de tereddütleri bulunduğunu, bunlarla ilgili olarak da kaygılandığını ifade etmiştir. Meslek seçimindeki ya da ilişkisindeki soru işaretlerine rağmen çözüme yönelik herhangi bir harekete geçmediğinden şikayet etmiştir. Ayrıca, M. Hanım son dönemlerde özellikle nişanlısı ile ilişkisindeki sorunlarının arttığını ve bu sorunları tolere etme eşiğinin düştüğünü, bu sebeple hayatında değişiklikler yapmak adına cesaret ve güç kazanmak amacıyla terapiye başlamaya karar verdiğini vurgulamıştır.

Yapılan klinik değerlendirmenin ve terapi sürecinde getirilen şikayetlerde ortaya çıkan temaların neticesinde, M. Hanım'ın histerik yapıya uygunluk gösterdiği düşünülmüş ve terapi süreci histerik yapı çerçevesine dayanılarak planlanmıştır. Çalışmanın bu kısmında histerik yapıya has özellikler terapide ele alınan temalar ile birlikte tartışılacaktır. Histerik yapıya işaret eden ana temalar süregelen memnuniyetsizlik ve mutsuzluk hali, kusur bulma eğilimi, kendini mağdur olan kişi olarak konumlandırması ve bununla birlikte ortaya çıkan, özellikle nişanlısı ile ilişkisinde sıklıkla gözlenen, sadist-mazoşist ilişkilenmesidir. Beliren temaların ortak özelliklerine bakıldığında, 
M. Hanım vakasının histeriğin arzusu kavramı ile ilişkili bir şekilde açıklanmasının ve örneklendirilmesinin uygun olabileceği sonucuna varılmıştır.

İlk olarak histerik öznenin kendisini, etrafinda bulunan/ilişkide olduğu insanlarla tanımlaması ile başlanabilir. Daha önce de belirtildiği gibi histerik özne, Ötekinin arzu ettiği ya da eksik olduğu olmak ister ve varlığının temel duruşu da Ötekini tamamlamaktır. Bu sebeple, M. Hanım nişanlısının arzusunu yerine getirebilmek için onun kendisinden ne istediğini bilmek istemektedir. Nişanlısının bir kadından ne beklediğini öğrenmek ve öyle bir kadın olabilmek için büyük bir uğraş vermektedir. Böylelikle hem nişanlısı tarafından arzulanıp kabul edilecek hem de ondan istediklerini alabilecektir. Bu nedenle ilişkisini sürdürebilmek adına kendisini nişanlısının ihtiyaçlarına adamakta ve zaman zaman da kendi istek ve ihtiyaçlarından feragat etmektedir. Örneğin nişanlısının kendisini hem ekomomik hem de duygusal anlamda muhtaç ve ihtiyaç içinde görmek istediğini söylemektedir. M. Hanım da bunun üzerine, kendi başına üstesinden gelebileceği durumlar olduğunda dahi idare etmek yerine nişanlısından destek istediğini ve onsuz yapamayacağını göstermeye çalıştığını belirtmektedir. Çünkü nişanlısını yakınında tutabilmek için ona güçsüzlük ve çaresizliğini göstermek zorunda olduğunu düşünmektedir. M. Hanım’a göre, eğer kendi başına yetebildiği ve aslında ona muhtaç olmadığı anlaşılırsa nişanlısının kendinden uzaklaşma ihtimali oluşacaktır. Benzer şekilde, M. Hanım evle ilgili tüm sorumlulukları almaktan ve nişanlısının bu konuda ona karşı tutumlarından hoşlanmasa da, nişanlısına belli etmemekte, onun arzu ettiği şekilde davranmaya devam etmeye çalışmaktadır. M. Hanım'ın ilk etapta oldukça fedakarca görülen ilişkilenme biçimi aslında nişanlının gözündeki arzulanan nesne olma konumunu korumak için bir yol oluşturmaktadır. Ayrıca ilgili yazında bahsi geçen tatmini fedakarlıktan ve adanmışlıktan alma durumunun M. Hanım için de geçerli olabileceği düşünülmektedir.

Bir başka dikkat çeken nokta da M. Hanım'ın ısrarlı bir biçimde nişanlısının kendisi için fedakarlık yaptığını görmek istemesi olmuştur. Kendisi için planlanan özel bir seyahat, doğum gününde yazılan bir mektup ya da zorla da olsa harcamalarının ödenmesi gibi durumlar beklenen özveriye örnek olarak verilebilir. Görüldüğü üzere nişanlısından asıl isteği, onun bir şekilde eksilmesidir. Bu eksilme duygusal ya da ekonomik olarak olabilir. M. Hanım’ın nişanlısından kendisi için fedakarlık yapmasını ya da bir şeylerden vazgeçmesini istemesi, nişanlıda bir eksiklik yaratma ve sonrasında onun eksiğini doyurma arzusundan kaynaklanıyor olabileceği düşünülebilir.

Aynı şekilde M. Hanım nişanlısını yalnız bırakmak istemediğini, çünkü bir süre ayrı kalsalar nişanlısının onu unutacağından ya da aldatacağından ve ayrılmak zorunda kalabileceklerinden korktuğunu söylemektedir. Bu nedenle mümkün olduğu kadar nişanlısının yanında olmaya çalıştığından bahsetmektedir. Nişanlısından birkaç gün bile ayrı kalsa içinde "bir süredir bir şey 
yemiyor içmiyormuş gibi bir boşluk oluştuğunu" dile getirmekte ve ona yakın olmanın ve dokunmanın yaşamsal ihtiyaçları kadar elzem olduğunu söylemektedir. Ayrıca M. Hanım nişanlısı yakınlarında olmadığında “dünyanın sonu gelmiş gibi hissettiğini” ve zaman zaman ona ulaşamamanın kendisi için “bir ölüm kalım meselesine” dönüşebileceğini ifade etmiştir. Bu anlatılar göz önüne alındığında, M. Hanım'ın daimi bir biçimde ilgi beklediği ve ilgiyi alamadığında da terkedilme tehdidi yaşadığı sonucuna varılabilir. Bu durum, M. Hanım'ın yalnızlığa tahammülü olmadığı izlenimini yaratsa da, varlığını güvence altına almak için Ötekine ihtiyaç duyuyor olabileceği düşünülmektedir.

Ek olarak M. Hanım nişanlısının arzusunu dikkatle yakından incelemekte ve diğer kadınlara yönelik bir ilgisinin olup olmadığını saptamaya çalışmaktadır. M. Hanım’a göre her ne kadar beş yıllık ilişkileri boyunca nişanlısı ilişkiye sadık olsa da kendisini nişanlısının bir başka kadınla ilişki yaşıyor olabileceği hayalinden uzaklaştıramamakta, dolayısıyla da her zaman bu düşüncesini destekleyecek ipuçlarını aramanın peşine düşmektedir. Bu amaç doğrultusunda nişanlısının kişisel eşyalarını, kayıtlarını, yazılarını karıştırmaktan ve dışarda olduğu her an onu aramaktan çekinmemektedir. Bilinç düzeyinde aldatılıyor olmaktan büyük bir korku duyuyor olsa da; aynı zamanda nişanlısının gözünde bir başka kadına yönelik bir arzuyu sezmeyi istiyor gibi görünmektedir. Nişanlının başka bir kadınla ilişkisi olabilmesine yönelik bir istek, M. Hanım’nin en büyük endişelerinden birisi olan terkedilme korkusunun doğuracakken aynı zamanda da nişanlısının arzusunun ne olduğu ile ilgili ipucu verecektir.

M. Hanım aldatılmaktan ya da nişanlısını kaybetme ihtimalinden korkmasına rağmen, diğer erkeklerle iletişiminde oldukça flörtöz bir tarz benimsemektedir. Bu davranıştaki motivasyonunu, nişanlısının yaşadığı/yaşayacağı kıskançlık sonrasında kendisine yönelik tutumundaki değişiklikler oluşturmaktadır. M. Hanım nişanlısının böyle durumlarda diğer erkekle yarışa girdiğini ve kendisine bir "prenses" gibi davrandığını belirtmektedir. M. Hanım girilen bu yarışı nişanlısının arzusundaki yerinin kanıtı olarak görmektedir. Örnek olarak eski erkek arkadaşını, P. Bey’i, içeren bir yaşantısı verilebilir. M. Hanım davet edildiği bir etkinliğe P. Bey’in de geleceğini öğrenmiş, o andan itibaren bütün haftasını P. Bey’in kendisinin ne kadar mutlu olduğunu gördükten sonra yaşayacağı pişmanlık ve perişanlığı hayal ederek geçirmiştir. Ayrıca tüm hafta boyunca, P. Bey’i kıskandırmak, üzmek ve kendisini tekrar elde etmeyi arzulamasını sağlamak için neler yapabileceğini planlamıştır. M. Hanım ayrıldıkları günden itibaren geçen uzun yıllar boyunca bir gün tekrar biraraya geldiklerini ve P. Bey’in kendisine ne kadar aşık olduğunu hatırladığını hayal ettiğini belirtmiştir. Bahsi geçen etkinliğe gittiklerinde de nişanlısına P. Bey’i gösterdiğini ve nişanlısının kıskanarak kendisine istediği gibi nazikçe davrandığını söylemiştir. Sonuç olarak etkinlikte olaylar M. Hanım'ın istediği 
gibi gitmiş hem nişanlısını hem de P. Bey’i kıskandırarak ikisinin de arzu nesnesi olma konumunu sürdürebilmiştir.

M. Hanım nişanlısıyla ilişkisinde sorun çıkarmak konusunda tereddüt etmemektedir. Nişanlısından ya yapılması onun için imkansız bir şey istemekte ya da ne istediğini açık bir şekilde ifade etmeden isteğinin gerçekleşmesini beklemektedir. İki türlü de isteğinin gerçekleşmemesini garantiye almaktadır. Bu durum Ötekinde sürekli olarak M. Hanım’ın gerçekte ne istediğini anlamak ve onu memnun etmek için bir çaba oluşmasına neden olmaktadır. Nişanlısı onu tatmin etme arzusuna sahip olurken, M. Hanım da arzulanan nesne, aynı zamanda da arzusu doyurulmaya çalışılan özne konumuna geçmektedir.

M. Hanım standartlarını yüksek tutmakta ve karşılanmayacaklarından emin olmaktadır. Nişanlısı isteklerine cevap vermeye çalıştığı zaman ya isteklerini değersizleştirerek ya da memnun etme çabasını küçümseyerek onu durdurmaya çalışmaktadır. Neticede nişanlısı yılgınlığa uğramakta ve isteklerine cevap vermeyi reddetmektedir. M. Hanım her defasında aynı sonucu alacak şekilde davranmakta, hem kendi hem de nişanlısının arzusu tam da istediği gibi tatminsiz kalmaktadır. Ancak M. Hanım nişanlısının kendisini tatmin etme arzusundan vazgeçmek üzere olduğunu fark ettiği anda geri adım atmaktadır. Çünkü bu durum onun nişanlının gözündeki arzu nesnesi olma konumunu tehlikeye atmakta olup aynı zamanda onun varlığını tehdit etmektedir. Bu nedenle M. Hanım nişanlısının arzusunu doyurmaya çalışan, fedakar ve özverili pozisyonuna geri dönmekte, bir kısır döngü içine girmektedir.

Bu noktada M. Hanım'ın döngüsü Freud'un hastasındaki duruma benzer bir hal almaktadır. Öyle ki Freud'un hastası gibi M. Hanım da partnerinde bir arzu uyandırmakta ancak bu arzunun doyumuna izin vermemektedir. Böylelikle M. Hanım iki şey elde etmiş olmaktadır: İlkinde nişanlısının arzusu canlı kalmakta bundan dolayı da arzu nesnesi olarak ya da Ötekinin arzusunun nedeni olarak pozisyonunu sürdürmektedir. İkincisinde ise kendi arzusunun doyurulmamış kalmasıyla asıl zevki almakta, arzuyu sürdürebilmenin zevkini devam ettirebilmektedir.

M. Hanım'ın arzunun gerçekleşmemesinin arzulanmasına yönelik arzusunu gösteren bir rüyası değerlendirilmiştir. M. Hanım yukarıda bahsedilen eski erkek arkadaşı P. Bey ile ilgili bir rüyayı paylaşmıştır. Rüyasında P. Bey ile karşılaştığını ve birbirlerini görür görmez etrafa aldırmadan öpüşmeye başladıklarını ve sonrasında bilmedikleri bir eve gittiklerini orada günlerce seviştiklerini söylemiştir. Birkaç gün sonra uzaktan nişanlısının gelişini gördügünü ve paniklemiş bir biçimde ona durumu nasıl açıklayacağını düşünürken, nişanlısının ayrılmak istediğini söylediğini belirtmiştir. Nişanlısı oradan ayrıldıktan sonra “artık P. ile legal bir ilişkimiz olabilir” diye düşündüğünü, ama bu düşünce aklında belirir belirmez şimdiki ilişkisinde yaşadığına benzer bir 
mutsuzluk ve sıkıntı hissettiğini eklemiştir. Aklında P. Bey’e ilişkin "Bizim geleceğimiz ne olacak?" ve "Beni seviyor mu, sevmiyor mu?” gibi soruların belirdiğini ifade etmiştir. Rüyayı anlattıktan sonra M. Hanım'a düşünceleri sorulduğunda, rüyasında bile mutlu olamadığını, her zaman mutsuz olmak için nedenlerinin olduğuna inandığını ifade etmiştir. Rüyada M. Hanım, P. Bey’e tekrar kavuşma ve yeniden aşık olunma arzusuna sahip olmuş görünmektedir, ancak hali hazırda bu arzunun gerçekleşmesi ile ilgili bir mutsuzluk ve ızdıraptan bahsetmektedir. Bu nedenle rüyanın içeriğinin, M. Hanım'ın tatmin olmamaya yönelik arzusuna bir örnek olabileceği düşünülmektedir. Rüyadaki bir diğer önemli nokta, M. Hanım’ın nişanlısının ilişkiye devam etmek istemediğini söylemesiyle onun gözündeki arzu nesnesi yerini artık kaybetmesidir. Aynı zamanda P. Bey ile kavuşarak onun zevk nesnesi olma riskiyle karşı karşıyadır. Bu iki durum da histeriğin varlığı için tehdit oluşturan koşullardır. Çünkü daha önce bahsedildiği gibi histerik arzunun sebebi olmak istemekte ama zevk nesnesi olmayı reddetmektedir.

M. Hanım'ın zevk nesnesi olmayı reddetmesi gerçeği cinsel yaşamı ile ilgili ifadelerinde açıkça görülmektedir. M. Hanım cinsel yaşamını sıradan, sıkıcı, "olması gerektiğgi” gibi olarak tarif etmekte ve nişanlısı ile direk fiziksel ve cinsel yakınlaşmadan kaçındığını, çok nadiren nişanlısının cinsel ilişkiye girme teklifine olumlu yanıt verdiğini belirtmektedir. M. Hanım'ın flört etmekten ve önsevişmeden cinsel ilişkiye kıyasla daha çok keyif aldığı anlaşılmaktadır. Bu durum, M. Hanım’ın nişanlısı ve eski erkek arkadaşı ile yaşadığı cinsel deneyimleri kıyaslamasında da anlaşılmaktadır. M. Hanım iki ilişkiyi şehvetli ve şefkatli olarak kategorilere ayırmaktadır. Eski erkek arkadaşla tam bir cinsel birleşme yaşamadıklarını ama birkaç kere halka açık yerlerde, kimseye görünmeden ama yakalanma tehlikesiyle yakınlaştıklarını ve bunu oldukça tutkulu bulduğunu söylemiştir. Buna karşın nişanlısıyla tam bir cinsel birleşme yaşamalarına, hiçbir yakalanma riski olmadan hatta romantik şekillerde bu birlikteliği yaşamalarına rağmen, bu deneyimi sıkıcı ve ortalama olarak nitelendirmiştir. M. Hanım'ın yaklaşımının histerik yapıyla örtüştügü düşünülmektedir. M. Hanım arzulamayı ve arzulanmayı sürdürmek istemekte, bu nedenle tam bir cinsel birleşmenin zevkini yaşamak yerine, tamalanmamış önsevişmeyle arzusunu doyumsuz kılmaktadır. Histerik için arzulanmanın devamlılığı varlığının sürmesi açısından önem arz etmektedir.

Son olarak, verilen örneklerde histerik yapının zevkten hoşlanmadığı ya da tiksindiği yönünde bir tablo oluşmuş gibi görünmesine rağmen, bu histerik öznenin zevke dair bütün ilişkileri kesip attığı anlamına gelmemektedir. Histerik özne, zevke karşı kendisini savunur ama bastırılanın geri dönüşü sebebiyle savunmaları düşer ve bu düşüş semptomu ortaya çıkarır. Histerik öznenin zevki semptomda görülür, semptomda yaşanır (Soler, 1996). Bu sebeple M. Hanım'ın başlangıçta terapiye getirdiği somatik yakınmaları tamamıyla zevk çıkarmanın araçları olarak düşünülebilir. 
Ayrıca M. Hanım'1n tatmini reddetmesi ve kendini tatminden/doyumdan yoksun birakması da zevke ulaşma biçimi olarak kabul edilebilir.

\section{Terapi Sürecinde Histeri}

Histeriğin Öteki ile ilişkilerinde aldığı roller ya da konumlar, terapi ortamında da aynı şekilde tekrarlanmaktadır. Histeriğin varlığını kurabilmesi ve sürdürebilmesi Ötekine bağlı olduğu için, histerik özne kolaylıkla Ötekinin yardımını istemekte, yani terapiye başvurmaktadır (Gessert, 2014). Histerik özne kendisiyle ilgili bilgiler sormaktadır: "Benim neyim var?" ya da "Benim sorunum ne?" gibi (Fink, 1997). Kim olduğu, semptomlarının ne anlama geldiği, daha mutlu bir birey olmak için ne yapması gerektiği gibi sorularına cevap bulabilmek istemektedir (Gessert, 2014). Terapistten varlığındaki boşluğu ve varlığına dair eksik olan bilgisini doyurmasını, doldurmasını istemektedir. Ayrıca Ötekine yönelik asıl sorusu “O benden ne istiyor?” olduğu için Ötekinin arzusunun ne olduğu ile ilgili sorunun da cevabını almak istemektedir (Fink, 1997).

Bu nedenle, histerik bir nevi terapistin bilgi üretmesi için onu çalıştırmakta, işletmektedir (Fink, 1997). Bu durumda analist histeriğin talebine uyar ve ona bilgi sağlamaya çalışırsa, ortaya çıkan bilgi yalnızca kısa bir süreliğine tatmin edici olmaktadır. Histerik neredeyse hemen, sunulan bilgiyi geçersiz kılmaya, sorgulamaya ya da değerlendirmeye başlamaktadır. Çünkü böylece terapistin bilgisindeki eksiği bulabilecektir (Fink, 1997; Gessert, 2014). Fink’e göre (1997), terapistinin bilgisinin doğruluğunu sorgulamak histeriğe terapistini tamamlayabileceği ya da onu geliştirebileceğine dair bir kanıt oluşturmakta ve yeni sorular üretmesi içinde zemin hazırlamaktadır. Başka bir deyişle, histerik özne kendisini Ötekinin bilgisinin efendisi konumuna yerleştirmekte ve üretilen bilginin değerini belirlemektedir (Soler, 1996). Histeriği bilgiyle doyurmaya çalışan terapist, er ya da geç bu oyunun kazananının her zaman histerik olduğunu anlar (Fink, 1997). Örneğin, analist histeriğin bir semptomunu anlamlandırmasında ya da semptomunun geçmesinde başarılı olmuşken, histerik diğer seansa yepyeni benzer bir semptomla gelebilmektedir (Fink, 1997). Böylelikle histerik hem Öteki için bir gizem olmaya hem de Ötekinin arzusunun nedeni olmaya devam edebilmektedir (Gessert, 2014).

Literatürde aktarılanlara benzer bir işleyiş, M. Hanım ile yürütülen süreçte de gerçekleşmiştir. Terapi sürecinin başlangıcından itibaren M. Hanım kendini keşfetmekle ilgili oldukça istekli ve işbirlikçi bir tutum sergilemektedir. S1k sık ne istediğini bilmediğini, neden sürekli benzer biçimde davrandığını anlamadığını vurgulamaktadır. Etrafındaki insanlara yönelik tutumlarından ve tutarsız/değişken duygularından yakınmaktadır. Ayrıca kendisinin ve nişanlısının esas arzusunun ne olduğunu sorgulamakta ve hem kendisini hem de nişanlısını anlamak istediğini belirtmektedir. Ancak, arzusunu ve ihtiyaçlarını anlamaya çalışırken tüm işi terapistten 
beklemektedir. Sadece sorular ve olaylarla gelmekte, cevapları ve yorumu terapistten istemektedir. Her ne kadar M. Hanım'ın talepleri ve deneyimleri seanslarda ele alınmaya çalışılsa ve yaşadıklarına birlikte anlam verme yoluna gidildiyse de, elde edilen bilgiler hiçbir zaman onun için yeterli olmamıştır. Terapist başlangıçta M. Hanım'ın yapısındaki oyuna düşmüş ve onun şikayetlerine cevap bulma çabasına girmiştir. Ancak M. Hanım sunulan bilgileri ya reddetmiş ya da terapist için bir başka sorun üretmiştir. Bu nedenle şöyle bir çıkarıma gidilebileceği düşünülmektedir: Histerik Ötekinin birçok şeyi bilen ve ona neyin doğru ya da yanlış olduğunu söyleyebilen efendi olmasını istemekte; ancak Ötekinin kendisiyle ilgili çok fazla şey bilmesini istememektedir. Bir başka ifadeyle, histerik kendisinin hükmedeceği bir efendi istemekte, Ötekinin yönetimini reddetmektedir (Eyers, 2012; Lacan, 1970). Bu durum tıpkı daha önce bahsedilen histeriğin arzu nesnesi olmak istemesi fakat bunu doyuran zevk nesnesi olmak istememesi durumuna benzemektedir. Ötekinin merak ettiği ve cevaplarını bildiği bir nesne gibi görünürken, aynı zamanda tam olarak anlaşılamayan, çözülemeyendir.

Lacan histeriğin bu sonu gelmez sorularını histerik söyleminde açılamıştır. Histerik söylemde, bölünmüş özne (analizan) efendi konumundaki Ötekinden (analist) cevap istemektedir. Ancak analistin cevabı histerik için hiçbir zaman nihai cevap olmayacaktır (Varheaghe, 2004), çünkü histeriğin duymayı istediği cevap, temelde bulmaktan kaçındığı cevaptır (Eyers, 2012). Aslında histerik özne Öteki ile ilişkisinde sonu gelmez arayışların içerisindedir (Varheaghe, 2004). Sonuç olarak, hiçbir cevap histeriğin sorusunu sona erdiremediğine ve histeriğin gizemini çözmeye yeterli gelmediğine göre, histeriğe verilebilecek tek doğru cevap hiç cevap vermemektir (Gherovici, 2014). Analist histeriğin sorularına cevap bulmak yerine, soruyu ona yönlendirmeli ve ne istediğini sormalıdır (Fink, 1997).

Analizin amacı eksiksiz bir özne yaratmak için histeriğin eksiğini tamamlamak ya da nevrotik yapısını ortadan kaldırmak değildir (Gessert, 2014). Aksine analizdeki asıl amaç, ortaya çıkan bilgiyle birlikte histeriğin kaybıyla ilişkisinde temel bir değişikliğe gidebilmesinin sağlanmasıdır. Histeriğin bu kaybı, onun benliğinin ya da varlığının oluşmasında kritik bir önem taşımakta ve analizde de bu kayba ilişkin farkındalık kazandırılmasının hedeflenmesidir. Ayrıca histeriğin bu kayıpta Ötekinin etkili olmadığı, bu sebeple de Öteki tarafından çözümlenemeyeceğine yönelik bir farkındalığının oluşturulmasıdır. Dolayısıyla analiz sürecinde özne, eksiğinden kaçırılmak yerine, aksine bununla yüzleştirilmeli ve arzusunun bu eksiklikten kaynaklandığını anlamal1 ve kabullenmelidir (Gessert, 2014).

Verilen yazın bilgisine uygun olarak, M. Hanım ile yürütülen süreçte, bugüne kadar gelinen aşamada, M. Hanım tatminsizliğini ve memnuniyetsizliğini sürdürmek konusundaki eğilimini fark 
etmek ve kabul etmek konularında çalışılmaktadır. Ayrıca tarif ettiği ve şikayetçi olduğu memnuniyetsizliğin aslında onu memnun eden bir yanı olabileceği ile ilgili sorgulamalar yapılmaktadir.

\section{Sonuç}

Histeri, bir patoloji olarak kabul edildiği ilk günden günümüze kadar memnuniyetsizlik ile ilişkilendirilmiştir (Varheaghe, 2004). Evan'ın bahsettiğine göre (1996), arzu her zaman “başka bir şeyin arzusudur" (Lacan, 1957); bu sebeple, hiçbir zaman tatmin edilemezdir, çünkü öznenin hali hazırda sahip olduğu bir şeyi arzulaması imkansızdır. Dolayısıyla, arzu nesnesi sürekli ertelenmekte ya da geciktirilmektedir (Evans, 1996). M. Hanım ile yürütülecek ileriki seanslarda, ona mutlak bir tatminin ya da mutluluğun olmayacağı, bunun insanın eksikli yapısına uygun olmadı̆̆ı ve bu sebeple de Ötekinin kendisini memnun etmek için verdiği tükenmek bilmeyen çabanın ona hiçbir zaman yeterli gelmeyeceği ve onu tatmin etmeyeceği konusunda farkındalık yaratma yoluna gidilmesi planlanmaktadir (Varheaghe, 2004).

Ayrıca, M. Hanım ile çalışmaya devam ederken dikkat edilmesi önemli bir diğer nokta da arzu nesnesini bulmaya yönelik bir arayışa girilmemesi; aksine arzuladığı konum ve özdeşleştiği kişilerin açığa çıkarılması ile ilgili çalışılmasıdır (Evans, 1996). Bununla ilgili olarak kaybıyla yüzleşmesi yolunda geçmiş deneyimlerini konuşarak düşüncelerini ortaya çıkardıktan sonra tekrar yapılandırmak önemli bir adımı oluşturmaktadır. Sonuç olarak terapi sürecinin nihai hedefi, M. Hanım'ın geçmiş yaşamına dair imgeleminde oluşturduğu tutarsız ve uyumsuz bilgilerin konuşma yardımıyla yeniden değerlendirilerek sembolik alana geçişinin sağlanmasıdır. 


\section{Kaynakça}

Evans, D. (1996). An Introductory of Lacanian Psychoanalysis (ss. 36-40). New York: Routledge. Eyers, T. (2012). Lacan and the Concept of the "Real" (ss. 96-103). New York: Palgrave MacMillian.

Fink, B. (1995). The Lacanian Subject: Between Language and Jouissance (ss. 75-79, 112-165). Princeton, New Jersey: Princeton University Press.

Fink, B. (1997). A Clinical Introduction to Lacanian Psychoanalysis: Theory and Technique (ss. 311). Cambridge, Massachusetts: Harvard University Press.

Freud, S. (1900). The Interpretation of Dreams: Distortion in Dreams. İçinde J. Strachey in Collaboration with A. Freud, A. Strachey, A. Tyson, \&A. Richards (Ed. \& Çev.). The Standard Edition of the Complete Psychological Works of Sigmund Freud. London: The Hogart Press.

Gessert, A. (2014). Hysteria and obsession. İçinde A. Gessert, (Ed.), Introductory Lectures on Lacan. London: Karnac Books.

Gherovici, P. (2014). Where have the hysterics gone?: Lacan's reinvention of hysteria. European Society of Cardiology, 40(1), 47-70.

Lacan, J. (1957). The instance of the letter in the unconscious, or reason since Freud. İçinde B. Fink in Collaboration with H. Fink and R. Grigg (Ed. \& Çev.). Ecrits: The first Complete Edition in English. New York, Norton \& Company.

Lacan, J. (1958). The direction of treatment and the principles of its power. Iç̧inde B. Fink in Collaboration with H. Fink and R. Grigg (Ed. \& Çev.). Ecrits: The first Complete Edition in English. New York, Norton \& Company.

Lacan, J. (1960). The subversion of the subject and the dialectic of desire in the Freudian unconscious. İçinde B. Fink in Collaboration with H. Fink and R. Grigg (Ed. \& Çev.). Ecrits: The first Complete Edition in English. New York, Norton \& Company.

Lacan, J. (1961). The Seminar of Jacques Lacan Book VIII, Transference (p. 345). (C. Gallagher, Çev.).

Lacan, J. (1970). The Seminar of Jacques Lacan Book XVII, Psychoanalysis upside down/The reverse side of psychoanalysis (ss. 108, 165-166, 260). (C. Gallagher, Çev.).

Lacan, J. (1981). The transference and the drive. İçinde J. A. Miller, (Ed.), The Seminar of Jacques Lacan Book XI, The Four Fundamental Concepts of Psychoanalysis (ss. 158-216). New York: W. W. Norton \& Company. 
Palomera, V. (2012). The ethics of hysteria and psychoanalysis. The Sympton, 13. Erişim http://www.lacan.com/symptom13/?p=244

Soler, C. (1996). Hysteria and obsession. İçinde R. Feldstein, B. Fink, \& M. Jaanus, (Ed.), Reading Seminars I and II: Lacan's Return to Freud (ss. 248-283). Albany: State University of New York Press.

Soler, C. (1992). History and hysteria: The witty butcher's wife. Newsletter of the Freudian Field, $6(1 \& 2), 16-32$.

Varheaghe, P. (2004). On Being Normal and Other Disorders: A Manual for Clinical Psychodiagnostics (ss. 351- 397). London: Karnac Books. 